\title{
Okonkwo’s Fall: Multiple Perspectives
}

\author{
T S Varadharajan ${ }^{1 *} \&$ Dr. K. Ramesh ${ }^{1}$
}

${ }^{1}$ SASTRA University, Thanjavur, Tamil Nadu, India

* T S Varadharajan, E-mail: mphilvaradha@gmail.com

\begin{abstract}
This article aims at exploring the causes of the fall of Okonkwo, the protagonist of the Nigerian Novel. Things Fall Apart by the renowned novelist, Chinua Achebe. Though the novel mainly deals with the fall of Igbo Culture where Okonkwo has played the sheet anchor role in the novel, Things Fall Apart at the hands of British establishment in Nigeria, the other vital reasons that make him vulnerable will also be discussed at length in this article. It is from the study of the novel, it is established that the Igbo society that refuses to change itself could be one of the reasons for the fall. However, it is very clear that the changes should take place spontaneously and not by force which the Igbo society has been the victim and the representative, Okonkwo its scapegoat. The writers of the article make sure that the reading of this article will be an eye opener in terms of Nigerian consciousness as revealed in the novel,
\end{abstract} Things Fall Apart.

\section{Keywords}

Igbo-a community/society in Nigeria, Chi-Personal deity to Igbo People, Evil Forest-A place where Christian Missionaries were established

\section{Introduction}

\subsection{Okonkwo: Creator of His Own Chi}

Chinua Achebe reflects the strengths and weaknesses of the traditional Igbo society in his works. Things Fall Apart (1958), his first novel, is the response of an African to the effect of European colonization. It centres around the life of Okonkwo who has achieved respectability in the clan by his sheer hard work. S. A. Khayyoom observes that Achebe's protagonists are more "a psychic case than a character study" (p. 19). He adds that the transition in the values of Igbo community is "dramatized in Okonkwo, a man of action and Obeirika, a man of thinking" (p. 19). The fall of Okonkwo marks the completion of the transition of the clan. Sociological, psychological and even theological factors are attributed to his downfall. However, often it is interpreted as the combination of all these factors. This paper attempts to probe into the nature of his downfall further and highlights his inability to adapt himself to the changing environment. 


\section{Method}

The Igbo society believes in the role of "chi" (personal deity) which is considered responsible for the success of individuals. While the growth of man is determined by his "chi", it is also believed that only when a man says yes his "chi" says yes. The growth of Okonkwo in Umuofia sounds like a fairytale where his "chi" appears to say yes to all his endeavors. He has proved his wrestling skills when he was a young man by conquering the unconquerable Amalinze, the cat. He has also won two titles to earn a name for him among the Igbo clan. But the paradox that a man is guided by his personal deity while it will help only those who help themselves is also found in the character of Okonkwo. He is able to achieve greatness not by luck but only by hardwork. In fact, Okonkwo did not inherit any barn or title from his father. However, even in his father's lifetime, he began to lay the "foundations of a prosperous future" (Achebe, p. 18). Though his journey to success was slow and painful, he was determined to reach the destination by his perseverance.

Okonkwo's obsession with being successful in life is caused by the failure of his father Unoka. Unoka, unlike Okonkwo, was "lazy and improvident and was quite incapable of thinking about tomorrow" (Achebe, p. 4). He actually did not fit into the Igbo society where manliness and success are considered the hallmarks of real man. Okonkwo's obsession for social recognition and is the outcome of his inherent fear that he may inherit the qualities of his idle father Unoka who was titleless and considered a failure in Igbo society. Achebe portrays the contrasting nature of the father and son taking into account the value system of tradition Igbo society before the arrival of the Europeans. While Unoka was "tall, thin and had a slight stoop" (Achebe, p. 4) Okonkwo was "tall and huge...breathed heavily...and seemed to walk on springs" (Achebe, p 4). Another important difference is also exemplified by making the son a proud Egwugwu (masked person representing the spirit) while the father is loathed as an agbala (a man without titles). Even Unoka was aware of the greatness of his son and when Okonkwo, during his formative years, could not taste success because of incessant rain. He consoled him and added that he had "a proud heart. A proud heart can survive a general failure because such a failure does not prick its pride" (Achebe, p. 24, p. 25). After elaborately highlighting Okonkwo as a successful clansman, a role model to be emulated by the youngsters, Achebe portrays his dramatic fall from grace. But his inevitable fall is caused by his stubbornness to stick to his principles and inability to adapt to the changes taking place around him.

\subsection{Okonkwo-A Tragic Hero?}

Quite contrary to his success, both socially and economically, the end of Okonkwo in Things Fall Apart reminds us of the end of Othello, the tragic hero. Both of them meet their tragic end because of their inability to control their passion and failure in discerning things using their reasoning ability. While Othello does not have many advisors to find his own faulty judgement, Okonkwo, on the other hand, has Oberika and Uchendu, men of wisdom who accept reality without any bias. The success of Oknokwo is followed by eventual fall caused by his inability to adapt himself to the changes in the society. 
Often Okonkwo is called a tragic hero whose fall has signaled the downfall of the whole clan. Colonization is considered the reason for it. It is interesting to note that Adrew Foley considers colonization as one of the many reasons for his downfall. He endorses that "colonization may be merely one factor in a much larger framework of meaning within which Okonkwo's fate is played out" (p. 45). Further, Okonwo may not be called a tragic hero in the Aristotelian sense because it is difficult "to identify exactly what his supposed tragic flaw might be" (Andrew Foley, p. 46). He adds that limiting his flaws to his inflexibility, pride and ambition is "hopelessly inadequate" (p. 46).

Furthermore, although Okonkwo does seem in many ways to be a victim of forces beyond his control, it again proves difficult to identify the precise nature of these forces, which could be interpreted as anything from blind fate to divine justice to something as culturally rooted as the particularistic Igbo concept of the chi. Perhaps most problematically, there is the issue of the cultural clash between traditional Igbo society and Western civilisation. It is by no means easy to reconcile the rigidly patterned requirements of classical tragedy with this unprecedented and essentially modern historical phenomenon. (Andrew Foley, p. 46)

Similarly considering him as a tragic hero, in the African sense, calls for better understanding of its culture. The archetypal African tragic hero, according to Asumah Adade-Yeboah and Edward Owusu, is a "part of oral literature" (p. 37). Also, the Africans belief in rebirth and the role of the departed souls helping the living and guiding them leads to the conclusion that the sufferings of a tragic hero is not considered a case of "an isolated case of unrelieved suffering" (p. 37) but as a "projection of an entire span, not tragic and now comic" (p. 37). Thus the fate of an individual can be changed by the intrusion of divination and result in the "reversal of calamity" (p. 37). As a result Things Fall Apart is not to be considered a novel to arouse pity on the downfall of its protagonist and eventually the Igbo society. In fact, his suicide can even be considered an affirmative act of Okonkwo, his last effort to unite the clansmen against the colonizers.

\subsection{Manliness vs Weakness}

Throughout the novel Okonkwo is portrayed as a man with a penchant for expressing manliness in a male-chauvinistic patriarchal society. His has a well-built body and would occasionally stammer when he is angry. But he uses this disadvantage to his advantage by taking it as an opportunity to use his fist when could not get words quickly. As a man of quick temper Okonkwo used to beat his wives and ensured that he had kept his family members under control. He ruled his household "with a heavy hand" (Achebe, p. 13) and the hive wives and children feared his fiery temper. Though, down in his heart, he is not a cruel man, his exhibition of his manliness by controlling the family is actually the outcome of the fear hidden in the inner recess of his heart. Achebe reveals that this fear was "deeper and more intimate than the fear of evil and capricious gods and of magic, the fear of the forest..." (p. 13). But it was the fear of failures in life. 
It was the fear of himself, lest he should be found to resemble his father... And so Okonkwo was ruled by one passion-to have everything that his father Unoka had loved. One of those things was gentleness and another was idleness (Achebe, p. 13).

Eventually Okonkwo's quick temper is one of the causes for his son Nwoye deserting the family. Okonkwo, in fact, failed in his duty as a father by not being a perfect role model for his children. His preference for honour over love and affection is better understood when he says, "I will not have a son who cannot hold up his head in the gathering of the clan. I would sooner strangle him with my own hands" (Achebe, p. 33). A man like Okonkwo is expected "to flow with the cannons of the society without much struggle" (Maduagwu, p. 312). Instead, he succumbed to his own rash nature and acted against the laws of the Igbo society. His beating of his wife during the week of peace is condemned by the society. It is, thus, evident that Igbo clan does not consider mere physical strength as a sign of manliness. Actually masculinity in Igbo society demands that "one matures beyond the physical strongman to the level of self-controlling strongman, both of his internal self and his outer world" (Maduagwu, p. 312). Perhaps, Okonkwo's fault lies with his inability to control himself and eventually led to his downfall.

The fall of Okonkwo begins with the killing of Ikemefuna. When he was told about the idea of murdering Ikemefuna he did not oppose the clan's decision though he developed a liking for him. His weakness is exposed in his inability to speak leave alone acting against the clan. It can also be interpreted as Okonkwo's devotion to his clan. However, the fall of Okonkwo is first portrayed in the "female" crime (ochu) committed by him and the consequent exile he has to face. It is quite ironical that Okonkwo, despite his obsession with the concept of manliness, has committed a "female" crime and has lost his social recognition gained over several years of hardship.

\subsection{Okonkwo Versus Oberika}

While Achebe prepares the readers to witness the fall of Okonkwo, he contrasts the impulsive nature of Okonkwo with the rationality of his friend Obeirika. While being a true clansman, Obeirika, unlike Okonkwo, did not hesitate to express his views against the popular belief when they are unacceptable to him. He, in fact, warned his intimate friend Okonkwo not to be a part of Ikemefuna's killing as the boy has always considered him a father figure. While being saddened by the misfortune of Okonkwo that led to his exile, he is also obligated to destroy his house as demanded by the clan. He is aware of the inadequacies some of the Igbo custom and is sensible enough to accept them. On the contrary, Okonkwo refuses to be rational and is a blind devotee of the Igbo religion. Hence, his downfall actually symbolizes the fall of the clan and its religion.

\subsection{Native Religion vs Christianity}

Another factor attributed to the fall of Okonkwo and his clan is the gaining popularity of Christianity among the clansmen. Igbo society is built on its firm religious belief and the social practices to support it. The missionaries, after being allotted, a piece of land in the Evil Forest, a place haunted by evil spirits, were able to build a church and stay there to the surprise of the native people. They thought that 
“the white men's fetish had unbelievable power" (p. 149) and were attracted by the new religion. Further, Christianity gained popularity by admitting the osu, the social outcasts, and giving them social recognizance.

Okonkwo's exile in Mbanta makes him understand the harsh reality of the dominance of a society over an individual. The soothing words of his uncle Uchendu and the arrival of his friend, Obeirika, during the last few years of his exile do not comfort him. He is desperate to return to Umuofia and reestablish his credentials as an important member of the clan. But the arrival of the Missionaries and the not-so-vehement attitude of the clan towards them infuriate him as he perceives the Missionaries as forces that will threaten the existence of the native clan. Also, his efforts to kindle the passion of the clan to protect their culture and religion go in vain as others do not consider the arrival of the missionaries as a potential threat to the existence of their own religion. At first, they viewed the missionaries with skepticism which later became a cause of concern as the dissenters of the clan are provided with an opportunity to join hands and register their protest against the clan and its superstitious believes. For example, the disregarded osus of the Igbo clan is treated as human beings Father Brown. He, also, persuaded the other converts not to treat osus as social outcasts as all of them are children of God.

More importantly, the conversion of Nwoye signals the inability of Okonkwo in controlling both his family and the clan. At first, Nwoye, at first, kept his attraction towards the new religion a secret for the fear of his father. But once he got the courage to express his wish he left his home. Andrew Foley believes that "the ill nature his [Okonkwo's] chi seems confirmed when his despised son Nwoye, converts to Christianity" (p. 50).

\section{Result}

The suicide of Okonkwo is perceived as the symbolic representation of the disintegration of Igbo society. The new faith, according to S. A. Khayyoom, has put "a knife into the things that held the Igbos together, and Igbos have fallen apart" (p. 104). During the early twentieth century, when the impact of colonization was felt the fall of Okonkwo might appear to be desperate effort of to put the falling things intact. However, it is actually triggered by social, political and religious factors. In fact, with the rapid strides of science and technology the geographical boundaries are getting blurred and the modern world requires its citizens to adapt themselves to the changing circumstances. Okonkwo's inability to adapt himself to a new environment is an important reason for his tragic fall. Change is inevitable and so the rise and fall of Okonkwo is also relevant in the twenty-first century.

\section{References}

Achebe, C. (1994). Things Fall Apart. New York: Anchor Books, Print.

Adade-Yeboah, A., \& Edward, O. (2013). The Tragic Hero of the Modern Period-The African Concept. English Language and Literature Studies, 3(4), 37-45. 
Foley, A. (2001, August). Okonkwo's Fate and the World View of Things Fall Apart. Literator, 22(2), 39-59. Durbanville, AOSIS Publishing.

Khayyoom, S. A. (1999). Chinua Achebe: A Study of His Novels. New Delhi: Prestige, Print.

Maduagwu, C. (2011, December). Masculinities in Achebe's TFA. International Journal of Humanities and Social Science, 1(20), 311-317. 